E3S Web of Conferences 1, 33009 (2013)

DOI: $10.1051 / \mathrm{e} 3 \operatorname{sconf} / 20130133009$

(C) Owned by the authors, published by EDP Sciences, 2013

\title{
Metal Contaminated Dredged Sediment Derived Soils: A Case Of Diffuse Contamination
}

\author{
F. M. G. Tack ${ }^{1}$ and B. Vandecasteele ${ }^{2}$ \\ ${ }^{1}$ Ghent University, Department of Applied Analytical and Physical Chemistry, Laboratory of Analytical Chemistry and \\ Applied Ecochemistry, Coupure Links 265, B-9000 Ghent, Belgium, filip.tack@ugent.be \\ ${ }^{2}$ Institute for Agricultural and Fisheries Research (ILVO), Burg. Van Gansberghelaan 109, box 1, B-9820 Merelbeke, Belgium
}

\begin{abstract}
Significant areas in Flanders, Belgium exhibit moderate contamination with trace metals caused by deposition or disposal of contaminated sediments. After disposal, the sediments develop into a soil-like material, on which vegetation is planted or develops spontaneously. Behaviour, cycling and ecosystem impacts of trace metals in calcareous dredged sediment disposal sites in Flanders was investigated. Although soil physico-chemical properties favour a low metal bioavailability, pore water concentrations can be elevated compared to pore water in uncontaminated soils. While metal leaching is not considered to be of concern, several plants accumulate elevated levels of $\mathrm{Cd}$ and $\mathrm{Zn}$ in leaves. Also metal levels in soil dwelling organisms and small mammals, particularly $\mathrm{Cd}$, are elevated compared to reference situations. This raises concern for an enhanced transfer of metals to the food chain. A comprehensive knowledge of metal behaviour in these sites is essential for developing appropriate management options for these sites.
\end{abstract}

Key words: trace elements; plant uptake; soil biota; dredged sediment disposal

\section{Introduction}

Significant areas in Northern Belgium exhibit moderate contamination with trace metals caused by disposal of contaminated dredged sediments (Tack \& Vandecasteele, 2008) or by the periodical deposition of suspended contaminated sediments in floodplains (Du Laing et al., 2009; Teuchies et al., 2008). Although contamination might present environmental hazards, conventional remediation often is not feasible because of the large surface area and the relatively low metal concentrations. Only a well deliberated use of these sites that is designed at minimizing potential hazards of the contamination is left as a realistic alternative to deal with this contamination. Management options for these sites such as wetland conservation, afforestation, short rotation forestry or creation of landscape dikes can only be successful if they are based on a good understanding of the cycling and ecosystem impact of trace metals. A case study along the rivers Scheldt and Leie in Belgium is presented. In total, about 430 ha of soil along these rivers has been identified as affected by deposition or disposal of sediments. Traditionally, sediments dredged from inland water bodies were disposed along the shores and on agricultural land. Since the 70ties, sediments were disposed in confined disposal facilities (Vervaecke et al., 2001).

\section{Metal contamination}

Summary statistics of sediment properties and metal contents are provided in Table 1 . In about $85 \%$ of the areas affected by sediment disposal, regional soil remediation reference values were exceeded for at least one of the metals. Compared to remediation standard values, concentrations of $\mathrm{Cd}$ and $\mathrm{Zn}$ indicated severe pollution. Contamination with $\mathrm{Pb}$ was markedly less severe, while levels of $\mathrm{Cu}$ were well below remediation standard values, though still systematically above baseline level concentrations in the region (Vandecasteele et al., 2002).

Although physico-chemical conditions of the sediments, with neutral $\mathrm{pH}$, and high clay and organic carbon contents (Table 1), favour a low mobility of the metals, concentrations of several metals in the saturation extracts of oxic dredged sediment-derived soils in the region of Ghent were markedly above levels considered representative for pore-water of clean soils, between 5-10 $\mu \mathrm{g}$ $1^{-1}$ for $\mathrm{Cd}, 60-200 \mu \mathrm{g} \mathrm{l}^{-1}$ for $\mathrm{Cu}$, and $300-1000 \mu \mathrm{g} \mathrm{l}^{-1}$ for $\mathrm{Zn}$ (Tack \& Vandecasteele, 2008).

\section{Downward leaching of metals}

Leaching of metals from disposed dredged materials to the underground is greatly retarded because of the low hydraulic permeability of the substrates and the strong adsorption of 
Table 1. Summary statistics (median, minimum and maximum) of sediment properties and metal contents in dredged sediment derived surface soils along Scheldt and Leie.

\begin{tabular}{lrrr}
\hline & Median & Min & Max \\
\hline Clay $(0-2 \mu \mathrm{m} ; \%)$ & 35 & 12 & 55 \\
Sand $(>50 \mu \mathrm{m} ; \%)$ & 16 & 0 & 69 \\
$\mathrm{CaCO}_{3}\left(\mathrm{~g} \mathrm{~kg}^{-1}\right)$ & 72 & 32 & 133 \\
$\left.\mathrm{OC}(\mathrm{g} \mathrm{kg})^{-1}\right)$ & 51 & 20 & 104 \\
$\mathrm{pH}-\mathrm{H}_{2} \mathrm{O}$ & 7.5 & 7.0 & 8.1 \\
$\mathrm{EC}(\mathrm{dS} / \mathrm{m})$ & 0.52 & 0.13 & 2.33 \\
$\mathrm{Cd}(\mathrm{mg} / \mathrm{kg})$ & 9.9 & 0.5 & 47 \\
$\mathrm{Cu}(\mathrm{mg} / \mathrm{kg})$ & 125 & 5 & 180 \\
$\mathrm{~Pb}(\mathrm{mg} / \mathrm{kg})$ & 220 & 5 & 1300 \\
$\mathrm{Zn}(\mathrm{mg} / \mathrm{kg})$ & 1400 & 54 & 4400 \\
\hline
\end{tabular}

metals. It was estimated that migration of metals from dredged sediment-derived surface soil could result in yearly increases of total metal concentrations in $50 \mathrm{~cm}$ of underlying soil in the order of 2-4 $\mu \mathrm{g} \mathrm{kg}^{-1}$ for $\mathrm{Cd}$ and $\mathrm{Pb}$, $20-80 \mu \mathrm{g} \mathrm{kg}^{-1}$ for $\mathrm{Cu}$ and $100-500 \mu \mathrm{g} \mathrm{kg}^{-1}$ for Zn (Tack \& Vandecasteele, 2008). From long term leaching experiments using cascade leaching tests, the extent and importance of leaching was predicted to be of little concern. For example, accumulation of $\mathrm{Cd}$ after 500 years in a sandy soil was projected to be on average $0.05 \mathrm{mg} \mathrm{kg}^{-1}$ over a depth of 2.5 $\mathrm{m}$. In a clay soil, the amount of metals released after 500 years would be retained in $40 \mathrm{~cm}$ of underlying soil, with an average accumulation of $0.5 \mathrm{mg} \mathrm{kg}^{-1}$ (Tack et al., 1999).

\section{Uptake of metals in vegetation}

Ripened dredged materials are an excellent substrate for vegetation because of their favourable physical properties and chemical fertility (Bramley \& Rimmer, 1988). Recycling of elements through litter fall and litter decomposition can be an important pathway for input into the food web (Mertens et al., 2004). Despite physicochemical conditions favouring limited metal mobility, some plants can exhibit elevated metal concentrations in the above ground parts (Vandecasteele et al., 2002). Foliar Cd and $\mathrm{Zn}$ concentrations in willow $\left(>6.6 \mathrm{mg} \mathrm{Cd} \mathrm{kg}^{-1} \mathrm{DW}\right.$ and $>700$ $\left.\mathrm{mg} \mathrm{Zn} \mathrm{kg}^{-1} \mathrm{DW}\right)$ were elevated compared to concentrations observed in reference situations $(0.5-2.9$ and $128-338 \mathrm{mg}$ $\mathrm{kg}^{-1} \mathrm{DW}$ for Cd and Zn, respectively) (Vandecasteele et al., 2002). Other plants, such as ash, alder, maple and Robinia, do not accumulate metal levels in excess to these encountered in a not contaminated environment (Mertens et al., 2004; Vandecasteele et al., 2002). The hydrological condition of a site has a great influence on the availability of trace elements for uptake by plants. An upland hydrological regime resulted in elevated $\mathrm{Cd}$ and $\mathrm{Zn}$ concentrations in leaves of Salix cinerea, whereas concentrations were normal in a wetland hydrological regime (Vandecasteele et al., 2005). Maintaining a hydrological regime aiming at wetland creation is a potential management option for reducing bioavailability provided submersion can be maintained throughout the growing season (Vandecasteele et al., 2005).

\section{Uptake of metals in biota}

Different organisms accumulate markedly higher metal levels in ecosystems developed on contaminated dredged sediment-derived soils compared to unpolluted environments. Shells of the snail $C$. nemoralis living in contaminated sediments had increased levels of $\mathrm{Cd}$ and $\mathrm{Zn}$ whereas the levels of $\mathrm{Cr}$ and $\mathrm{Pb}$ remained below the limit of detection, despite elevated contents of these metals in the dredged sediment-derived soils (Jordaens et al, 2006). Leaf beetles on poplars showed higher body $\mathrm{Cd}$ concentrations than in reference situations, whereas $\mathrm{Zn}$ levels remained in the normal range (Vandecasteele et al., 2003). In small mammals (wood mouse, bank vole and common shrew) living in disposal sites for dredged sediment, levels of $\mathrm{Cd}$, but not $\mathrm{Zn}$, were strongly elevated compared with background levels. Potentially high concentrations in vegetation and small mammals indicate that ecosystem development should be considered carefully.

\section{Conclusions}

Considerable research in Flanders has focussed on ecosystems, developed on disposed contaminated calcareous dredged sediments in Flanders. It has allowed to appraise the extent of the hazard associated with the metal concentration levels, which frequently are significantly above baseline levels. Appropriate management of these sites must account for the contamination present. Although general physico-chemical conditions tend to favour a low mobility, there remains a potential of high uptake by specific plants and organisms. This warrants for a cautious management and use of these sites that accounts for the contamination present.

\section{References}

Bramley R G V, Rimmer DL. Dredged materials - problems associated with their use on land. J Soil Sci 1988; 39:469-482.

Du Laing G, Rinklebe J, Vandecasteele B, Meers E, Tack F. Trace metal behaviour in estuarine and riverine floodplain soils and sediments: A review. Sci Tot Environ 2009; 407:3972-3985.

Jordaens K, De Wolf H, Vandecasteele B, Blust R, Backeljau T. Associations between shell strength, shell morphology and heavy metals in the land snail Cepaea nemoralis (Gastropoda, Helicidae). Sci Tot Environ 2006; 363:285-293.

Mertens J, Vervaeke P, Schrijver AD, Luyssaert, S. Metal uptake by young trees from dredged brackish sediment: limitations and possibilities for phytoextraction and phytostabilisation. Sci Tot Environ 2004; 326:209-215.

Tack FMG, Vandecasteele B. Cycling and ecosystem impact of metals in contaminated calcareous dredged sediment-derived soils (Flanders, Belgium). Sci Tot Environ 2008; 400:283-289.

Tack FMG, Singh SP, Verloo MG. Heavy metal concentrations in consecutive saturation extracts of dredged sediment derived surface soils. Environ Pollut 1998; 103:109-115.

Tack FMG, Singh SP, Verloo MG. Leaching behaviour of 
$\mathrm{Cd}, \mathrm{Cu}, \mathrm{Pb}$ and $\mathrm{Zn}$ in surface soils derived from dredged sediments. Environ Pollut 1999; 106:107-114.

Teuchies J, De Deckere E, Bervoets L, Meynendonckx J, Regenmortel SV, Blust R, Meire P. Influence of tidal regime on the distribution of trace metals in a contaminated tidal freshwater marsh soil colonized with common reed (Phragmites australis). Environ Pollut 2008; 155:20-30.

Vandecasteele B, De Vos B, Tack FMG. Cadmium and Zinc uptake by volunteer willow species and elder rooting in polluted dredged sediment disposal sites. Sci Tot Environ 2002; 299:191-205.

Vandecasteele B, De Vos B, Tack FMG. Heavy metal contents in surface soils along the Upper Scheldt river (Belgium) affected by historical upland disposal of dredged materials. Sci Tot Environ 2002; 290:1-14.

Vandecasteele B, Du Laing G, Quataert P, Tack FMG.
Differences in $\mathrm{Cd}$ and $\mathrm{Zn}$ bioaccumulation for the flood-tolerant Salix cinerea rooting in seasonally flooded contaminated sediments. Sci Total Environ 2005; 341:251-263.

Vandecasteele B, Lauriks B, De Vos B, Tack FMG. Cd and $\mathrm{Zn}$ concentration in hybrid poplar foliage and leaf beetles grown on polluted sediment-derived soils. Environ Mon Assess 2003; 89:263-283.

Vandecasteele B, Quataert P, Tack FMG. The effect of hydrological regime on the metal bioavailability for the wetland plant species Salix cinerea. Environ Pollut 2005; 135:303-312.

Vervaeke P, Luyssaert S, Mertens J, De Vos B, Speleers L, Lust N. Dredged sediment as a substrate for biomass production of willow trees established using the SALIMAT technique. Biomass Bioenergy 2001; 21:81-90. 